\title{
N-Acetylcysteine Suppresses LPS-Induced Pathological Angiogenesis
}

\author{
Ping Zhanga,d Shan Zhong ${ }^{a, d} \quad$ Guang Wanga,d Shi-yao Zhang ${ }^{a, d}$ \\ Chang Chu $^{\mathrm{b}, \mathrm{e}}$ Shufei Zeng ${ }^{\mathrm{b}, \mathrm{e}}$ Yu Yan ${ }^{\mathrm{a}, \mathrm{d}}$ Xin Cheng ${ }^{\mathrm{a}, \mathrm{d}}$ Yongping Bao ${ }^{c}$ \\ Berthold Hocher ${ }^{a, b} \quad$ Xuesong Yang ${ }^{a, d}$
}

aDivision of Histology and Embryology, Internaitional Joint Laboratory for Embryonic Development \& Prenatal Medicine, Medical College, Jinan University, Guangzhou, China, ${ }^{b}$ Fifth Department of Medicine (Nephrology/Endocrinology/Rheumatology), University Medical Centre Mannheim, University of Heidelberg, Germany, 'Norwich Medical School, University of East Anglia, Norwich, United Kingdom, 'Key Laboratory for Regenerative Medicine of the Ministry of Education, Jinan University, Guangzhou, eDepartments of Nephrology, The First Affiliated Hospital, Jinan University, Guangzhou, China

\section{Key Words}

$\mathrm{N}$-acetylcysteine $\cdot \mathrm{NAC} \cdot$ Lipopolysaccharide $\cdot$ LPS $•$ Pathological angiogenesis $•$ Chick CAM - Oxidative stress

\begin{abstract}
Background/Aims: Angiogenesis is a key feature during embryo development but is also part of the pathogenesis of cancer in adult life. Angiogenesis might be modulated by inflammation. Methods: We established an angiogenesis model in chick chorioallantoic membrane (CAM) induced by the exposure of lipopolysaccharide (LPS), and analyzed the effects of the antioxidant $\mathrm{N}$-acetylcysteine (NAC) on angiogenesis in this model as well as on the expression of key genes known to involved in the regulation of angiogenesis. Results: Treatment with NAC was able to normalize LPS induced angiogenesis and restore the LPS-induced damage of vascular epithelium in chick CAM. Using quantitative PCR, we showed that NAC administration normalized the LPS induced expression of Keap1-Nrf2 signaling and oxidative stress key enzyme gene expressions (SOD, GPx and YAP1). Conclusion: We established a LPS-induced angiogenesis model in chick CAM. NAC administration could effectively inhibit LPS-induced angiogenesis and restore the integrity of endothelium on chick CAM. LPS exposure caused an increased expression of genes involved in oxidative stress in chick CAM. NAC administration could abolish this effect.




\section{Cellular Physiology Cell Physiol Biochem 2018;49:2483-2495

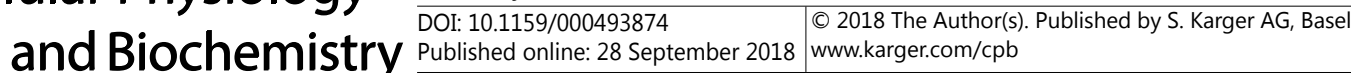 \\ Zhang et al.: NAC Suppresses LPS-Induced Pathological Angiogenesis}

\section{Introduction}

During embryogenesis the cardiovascular system develops and reaches full functional status at birth. This developmental of the cardiovascular system is caused by epigenetic mechanisms that are sensitive to eviromental challenges $[1,2]$ as well as direct effects of various drugs on embryonic development [3]. Normal vasculature development occurs typically at three different morphological stages, which includes vasculogenesis, angiogenesis and vascular remodeling [3]. Both vasculogenesis and angiogenesis are accomplished during the prenatal period. The formation of the primitive vascular plexus derived from hemangioblasts in extra-embryonic yolk sacs or from within the embryois the first step of vasculogenesis. Angiogenesis involves the expansion and remodeling of the vascular plexus through endothelial sprouting and intussusceptive microvascular growth [4]. It is a complex process and regulated by a many factors. An important stimulating factor of angiogenesis is VEGF, acting through VEGFR. VEGF is a specific mitogen which stimulates vasculogenesis and angiogenesis [5]. Another significant growth factor are the angiopoietins (Ang1 and Ang2) which are involved in the secondary stages of vessel growth and are required for the formation of mature blood vessels [6]. Fibroblast growth factor 2 (FGF-2), known for its angiogenic potential, is also of great importance in angiogenesis. One of the most important functions of FGF-2 is the promotion of endothelial cell proliferation and the physical organization of endothelial cells into tube-like structures, thus promoting angiogenesis [7].

Pathological angiogenesis is characterized by aberrant proliferation of blood vessels, seen for example during cancer formation. Another example of pathological angiogenesis is important for vision loss in diabetic patients. Here pathological angiogenesis is seen in the retina and may cause blindness [8]. Hypoxia is considered as an important factor in pathological angiogenesis, since hypoxia can activate the crucial angiogenesis mediators such as transcription factors hypoxia-inducible factor (HIF) and vascular endothelial growth factor (VEGF), which in turn promote tumor dissemination, invasion and metastasis $[9,10]$. Therefore, either laser photocoagulation or intravitreal injection of therapeutic antibodies binding VEGF is currently used for the treatments of pathological angiogenesis in diabetic patients [11]. However, there are many drawbacks for those therapeutic approaches because the consistent application is of inconvenience, low or variable efficacy, and costly. Thus, it is necessary to look for alternative treatment strategies, especially noninvasive and efficacious natural agents.

Pollet et al. reported that bacterial lipopolysaccharide (LPS) stimulated endothelial sprouting to initiate angiogenesis in vivo and in vitro through activating TRAF6-dependent signaling pathways [12]. Endotoxin and/or some cytokines stimulate pathological angiogenesis and the aberrant formation of new blood vessels [13]. Simon et al. reported that LPS exposure evoked cell death in umbilical vein endothelial cells through triggering ROS production [14]. In vivo studies demonstrated that LPS exposure caused large amounts of ROS production in activated microglia, which, in turn, cause neuronal damage [15]. Many compounds have been found to possess the inhibitory effect on LPS-stimulated reactive oxygen species (ROS) production [16].

Reactive oxygen species (ROS), as a component of oxidative phosphorylation, play an important role in the redox control of various signaling pathways [17-19]. However, excessive ROS generation in the body is associated with the pathogenesis of many diseases [1719]. Excessive ROS accumulation could interfere with cellular and physiological functions through deleterious oxidization of macromolecules including proteins, lipids, DNA and signal transduction [20]. ROS can act as primary or secondary messengers to promote cell growth or death, and oxidative stress could initiate crucial reactions that either positively or negatively influence embryonic development. Therefore, a fine balance between ROS production and degradation is key for normal physiological functions of the cell $[21,22]$. In this context, oxidative stress is regarded as a result of an imbalance between ROS generation 


\section{Cellular Physiology Cell Physiol Biochem 2018;49:2483-2495

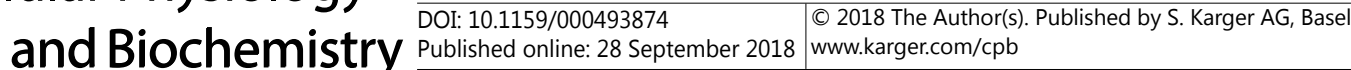 \\ Zhang et al.: NAC Suppresses LPS-Induced Pathological Angiogenesis}

and degradation. We have been interested in $\mathrm{N}$-acetylcysteine (NAC) since it could act as an antioxidants to restore intracellular levels of glutathione (GSH), the one of the body's most powerful antioxidant defenses [23].

NAC is a cysteine pro-drug, which has been used in therapeutic practices on the treatment of various disorders such as paracetamol intoxication for several decades [24]. As an antioxidants, NAC could also commendably diminish oxidative stress in patients with chronic obstructive pulmonary disease (COPD) [25, 26]. The function of NAC as antioxidation is achieved via its reaction with free radicals as well as the restitution of reduced glutathione (GSH) in numerous cells of the body $[24,26]$. In this study, we investigated the biological effect of NAC on the pathological angiogenesis using an in vivo chick ACM model.

\section{Materials and Methods}

\section{Avian embryos and treatments}

Fertilized chick eggs were obtained from the Avian Farm of the South China Agriculture University. For early gastrula embryos, HHO (Hamburger and Hamilton stage 0) [27] chick embryos were prepared and incubated in absence/presence of N-acetylcysteine (NAC) (Sigma, USA) or/and lipopolysaccharides (LPS, also called lipoglycans and endotoxins) (Sigma, USA) using early chick culture (EC culture) [28]. For later stage embryos, various concentrations of NAC $(200 / 400 / 800 / 1000 \mu \mathrm{g} / \mathrm{ml})$, LPS $(1 / 5 / 10 / 20 / 100 \mu \mathrm{g} / \mathrm{ml})$, Vitamin C (Vc) $(5 \mathrm{mg} / \mathrm{ml})$ or saline (control) were directly injected into the air chamber at the blunt end of the fertilized egg.

The embryos were harvested at desired time based on the experimental requirements after incubation at $38^{\circ} \mathrm{C}$. All of the embryos were photographed using a stereomicroscope (Olympus MVX10, Japan) before they were fixed with $4 \%$ paraformaldehyde for analysis of morphology and gene expression. Only the surviving embryos were used for further research. For the histological analysis, the treated embryos or yolk sacs were dehydrated, embedded in paraffin wax and serially sectioned at $5 \mu \mathrm{m}$ using a microtome (Leica RM2126RT, Germany). And then the sections were de-waxed in xylene, rehydrated and stained with either hematoxylin and eosin dye or immunofluorescent staining. The sections were photographed using a fluorescent microscope (Olympus IX50) with the NIS-Elements F3.2 software package.

\section{Assessment of angiogenesis using chick chorioallantoic membrane (CAM)}

As previously described [29], chick embryos were incubated until day 7 when chick CAM is well developed. The embryos were treated with NAC, LPS, or saline (control) for 48 hours and all surviving embryos were harvested for analysis. The CAM and accompanying blood vessels in the control, NAC and/ or LPS-treated embryos were photographed using a Canon Powershot SX130 IS digital camera (12.1M Pixels). Ten embryos in each experimental group were examined. CAM tissues from eight embryos in each group were embedded, sectioned and stained with hematoxylin \& eosin. The blood vessel density (BVD) were quantified using an IPP 5.0 image analysis program. The blood vessel density was expressed as the percentage of area occupied by blood vessel as previously described [30]. The chick CAM tissues were also harvested for biochemical assays as described below.

\section{The chick embryo aortic arch assay}

The aortic arches assay was done with minor modifications as reported previously [31]. Briefly, aortic arches of day 13 chick embryos are isolated and cut into small piece of rings tissues. The outgrowth of cells including the formation of vessel-like structures occurs mainly within 24-48 hours. The distance between cell emigrating from the aortic arches and the aortic arches is a parameter describing cell migration.

\section{Assessment of blood vessel integrality}

The assay of Evans blue (EB) (Sigma, US) leakage was used to evaluate blood vessel disruption following LPS, NAC, Vitamin C and saline treatment as described previously. The EB measurement was performed according to the previous study [32]. Briefly, $2 \% \mathrm{~EB}(4 \mathrm{ml} / \mathrm{kg})$ was injected via YSM. At $2 \mathrm{~h}$ after EB injection, YSM were harvest. The embryos for detecting the Evans blue contents were reperfused with PBS before 


\section{Cellular Physiology Cell Physiol Biochem 2018;49:2483-2495 and Biochemistry Published on \begin{tabular}{l|l} 
DOI: 10.1159/000493874 & (c) 2018 The Author(s). Published by S. Karger AG, Basel \\
www.karger.com/cpb
\end{tabular} \\ Zhang et al.: NAC Suppresses LPS-Induced Pathological Angiogenesis}

harvest. YSM samples were then homogenized by formamide (1 $\mathrm{ml}$ formamide/100 mg tissue) and incubated for $24 \mathrm{~h}$ at $60^{\circ} \mathrm{C}$ The absorbance of supernatants was measured at 620 $\mathrm{nm}$ [33] with microplate reader (Biotek, ELX800, US).

\section{Semiquantitative RT-PCR}

Total RNA was isolated from the gastrula chick embryos or chick CAM tissuesusing a Trizol kit (Invitrogen, USA) according to the manufacturer's instructions. First-strand cDNA was synthesized to a final volume of $25 \mu \mathrm{l}$ using SuperScript RIII first-strand (Invitrogen, USA). Following reverse transcription, PCR amplification of the cDNA was performed. The sets of primers used for semiquantitative RT-PCR are provided in the Table 1 . The PCR reactions were performed in a Bio-Rad S1000TM Thermal cycler (Bio-Rad, USA). The final reaction volume was $50 \mu \mathrm{l}$ composed of $1 \mu \mathrm{l}$ of first-strand cDNA, 25 $\mu \mathrm{M}$ forward primer, $25 \mu \mathrm{M}$ reverse primer, $10 \mu$ IPrimeSTARTM Buffer (Mg2+ plus), $4 \mu \mathrm{l}$ dNTPs Mixture (TaKaRa, Japan), 0.5 $\mu \mathrm{lPrimeSTARTM} \mathrm{HS} \mathrm{DNA} \mathrm{Polymerase}(2.5 \mathrm{U} / \mu \mathrm{l}$ TaKaRa, Japan), and RNase-free water. cDNA was amplified for 30 cycles. One round of amplification was performed at $94^{\circ} \mathrm{C}$ for $30 \mathrm{~s}, 30 \mathrm{~s}$ at $58^{\circ} \mathrm{C}$, and $30 \mathrm{~s}$ at $72^{\circ} \mathrm{C}$. The PCR products $(20 \mu \mathrm{l})$ were resolved using 1\% agarose gels (Biowest, Spain) in 1× TAE buffer (0.04 MTrisacetate and 0.001 M EDTA) and 10, 000x GeneGreen Nucleic Acid Dye (TIANGEN, China) solution. The resolved products were visualized using a transilluminator (SYNGENE, UK), and photographed using a computer-assisted gel documentation system (SYNGENE). Each of these experiments was replicated at least three times.

\section{Data analysis}

Statistical analysis for all the experimental data generated was performed using a SPSS 13.0 statistical package program for windows. The data were presented as mean \pm SE. Statistical significance were determined using paired t-tests, independent samples t-test or one-way analysis of variance (ANOVA). ${ }^{*} \mathrm{p}<0.05,{ }^{* *} \mathrm{p}<0.01$ and ${ }^{* * *} \mathrm{p}<0.001$ indicate significant difference between control and ethanol-treated specimens.

\section{Results}

Selecting the optimal concentration of NAC using gastrula chick embryos

To choose the optimal concentration of NAC, we incubated HHO chick embryos in EC culture containing 0 (control), 200, 400, 800, $1000 \mu \mathrm{g} / \mathrm{ml} \mathrm{NAC,} \mathrm{until} \mathrm{HH12} \mathrm{(Fig.} \mathrm{1A).}$ NAC showed a trend of a dose dependent increase in mortalitz, however, this effect was not significant (Fig. 1G); interestingly, exposing $800 \mu \mathrm{g} / \mathrm{ml} \mathrm{NAC} \mathrm{(3461 \pm 214.9 \mu m)} \mathrm{did} \mathrm{not}$ significantly alter the length of HH12 chick embryo compared to control $(3557 \pm 86.71 \mu \mathrm{m})$, although other concentrations of NAC stimulated the growth of gastrula chick embryos to some extent (Fig. 1F-H). Therefore, 400 and $800 \mu \mathrm{g} / \mathrm{ml}$ NAC are used in the following experiments.

\section{0 and $800 \mu \mathrm{g} / \mathrm{ml} \mathrm{NAC} \mathrm{administration} \mathrm{on} \mathrm{its} \mathrm{own} \mathrm{did} \mathrm{not} \mathrm{affect} \mathrm{angiogenesis} \mathrm{on} \mathrm{chick}$ CAM}

Using the angiogenesis model on chick CAM, we studied the effect of 400 and $800 \mu \mathrm{g} /$ $\mathrm{ml}$ NAC on the embryonic angiogenesis. NAC did not significantly affect the angiogenesis on CAM (Fig. 2B-D) as well as the blood vascular densities of the vascular nets on chick CAM (Fig. 2E). The expressions of oxidative stress-related key genes on chick CAM were assessed using quantitative PCR following the exposure of 400 and $800 \mu \mathrm{g} / \mathrm{ml}$ NAC (Fig. 2G-L). 
Fig. 1. Assessment of gastrula chick embryo development and mortality in absence/ presence of various concentration s of NAC. A: The sketches illustrate to incubation of $\mathrm{HHO}$ chick embryos until HH12 in EC culture in absence/presence of NAC (see also material and method for more details). B-F: Representive bright-field images of HH12 gastrula chick

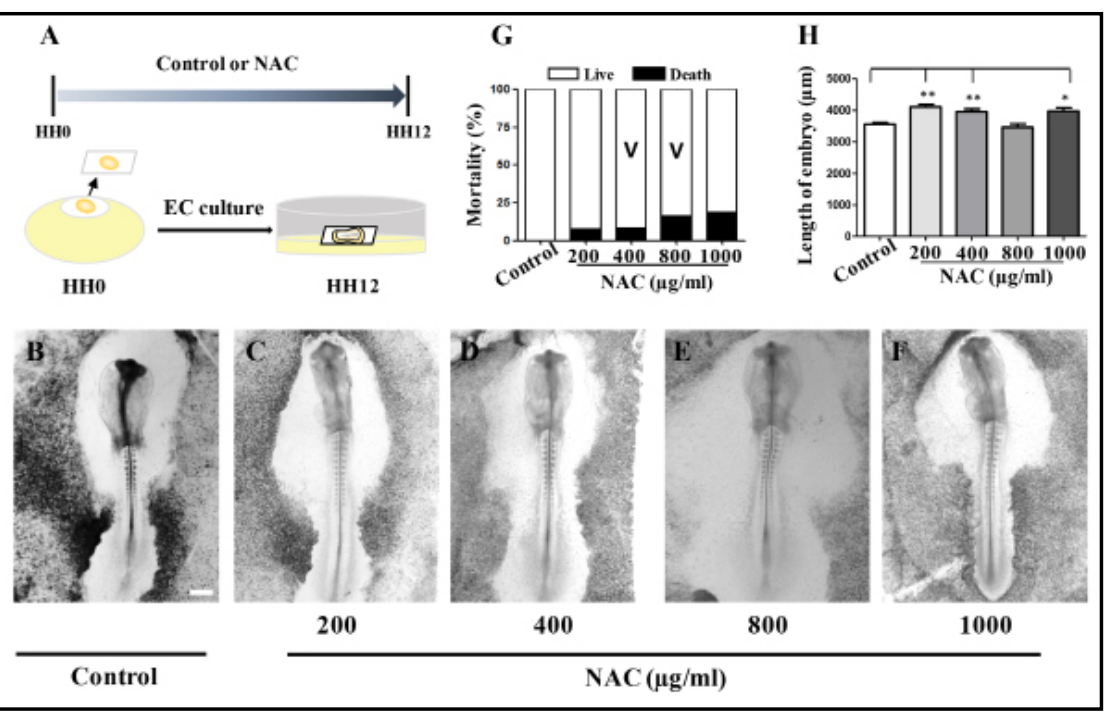
embryos were taken from saline treated control embryos (B), as well as embryos treated with $200 \mu \mathrm{g} / \mathrm{ml}$ NAC (C), $400 \mu \mathrm{g} / \mathrm{ml}$ NAC (D), $800 \mu \mathrm{g} / \mathrm{ml}$ NAC (E), $1000 \mu \mathrm{g} / \mathrm{ml}$ NAC (F) ,respectively. G-H: Bar graphs showing the comparison of mortality $(\mathrm{G})$ and lengths $(\mathrm{H})$ of the HH12 chick embryos either with saline (B) or with $200 \mu \mathrm{g} / \mathrm{ml} \mathrm{NAC} \mathrm{(C),} 400 \mu \mathrm{g} / \mathrm{mlNAC}$ (D), $800 \mu \mathrm{g} / \mathrm{ml}$ NAC (E), $1000 \mu \mathrm{g} / \mathrm{ml}$ NAC (F) , respectively. (n>3 chick embryos in each group). $\left({ }^{*} \mathrm{P}<0.05,{ }^{* *} \mathrm{P}<0.01,{ }^{* * *} \mathrm{P}<0.001\right.$ versus controls). Scale bars $=300 \mu \mathrm{m}$ in $\mathrm{B}-\mathrm{F}$.

Fig. 2. Assessment of NAC effects on angiogenesis and mRNA expression of key enzymes involved in ROS production in chick CAM. A: The sketches illustrate the experimental design of the experiment. NAC or saline were given at day 7 of embryo development. Angiogenesis and gene expression was assed at day 9. B-D: Representative bright-field image of angiogenesis on CAM

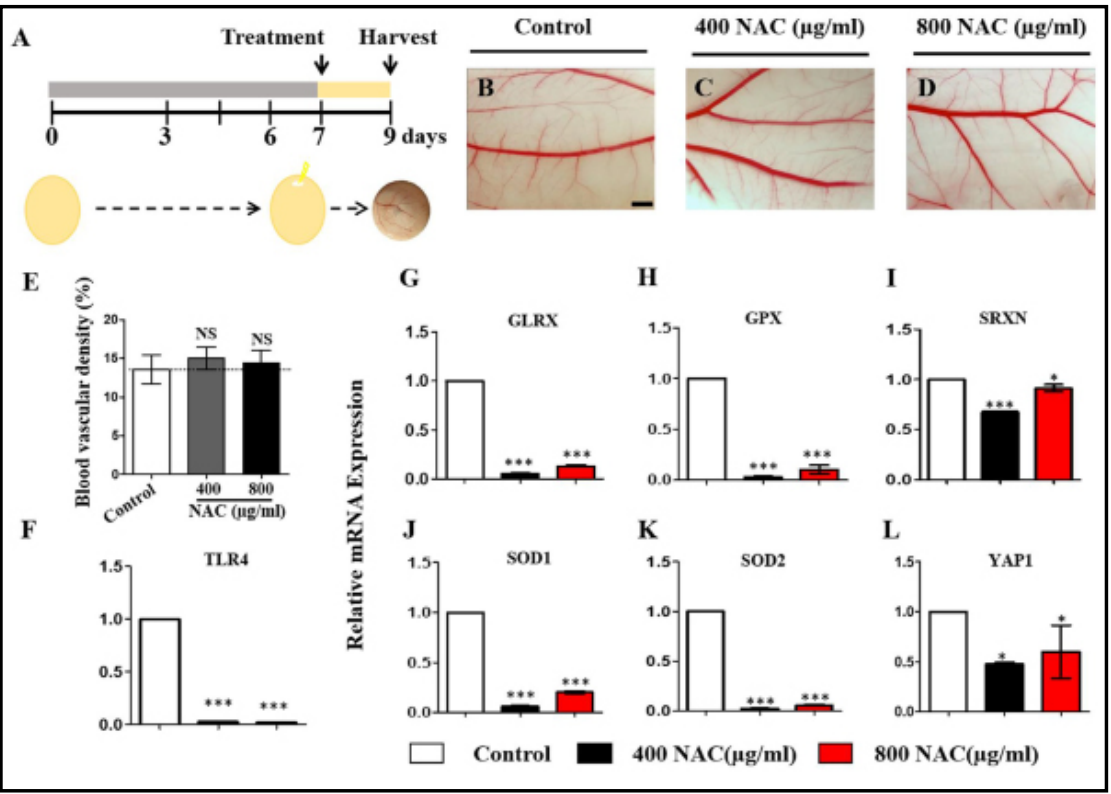
exposed to saline

(Control, B), $400 \mu \mathrm{g} / \mathrm{ml}$ NAC (C) and $800 \mu \mathrm{g} / \mathrm{ml}$ NAC (D), respectively. E: Bar graph showing blood vascular densities on the CAM in control embryos, embryos treated with $400 \mu \mathrm{g} / \mathrm{ml} \mathrm{NAC}$ and $800 \mu \mathrm{g} / \mathrm{ml}$ NAC groups. n>3 CAMs in each group. F-L: Quantitative PCR data show the gene expressions of TLR4 (F), GLRX (G), GPX (H), SRXN (I), SOD1 (J), SOD2 (K) and YAP1 (L) in control - saline treated - embryos, embryos treated with $400 \mu \mathrm{g} / \mathrm{ml} \mathrm{NAC}$ and $800 \mu \mathrm{g} / \mathrm{ml} \mathrm{NAC}$, respectively. (Each of these experiments was replicated at least three times.). $\left({ }^{*} \mathrm{P}<0.05,{ }^{* *} \mathrm{P}<0.01,{ }^{* * *} \mathrm{P}<0.001\right.$ versus controls). Scale bars $=1 \mathrm{~mm}$ in $\mathrm{B}-\mathrm{D}$. 
NAC administration suppressed LPS-induced angiogenesis on chick CAM and aortic arch explant models

Using the chick CMA model (Fig. 3A), we analyseddifferent combinations of LPS (10 and $100 \mu \mathrm{g} / \mathrm{ml}$ ) and NAC (400 and $800 \mu \mathrm{g} / \mathrm{ml})$ for 2 days. The results showed that both dosages of LPS increase blood vascular densities $(10 \mu \mathrm{g} / \mathrm{ml}$ LPS: $27.86 \pm 1.35, \mathrm{p}<0.001 ; 100 \mu \mathrm{g} / \mathrm{ml}$ LPS: $29.62 \pm 3.99, \mathrm{p}<0.001)$. The LPS-induced angiogenesis was significantly suppressed by NAC $(10 \mu \mathrm{g} / \mathrm{ml}$ LPS \& $400 \mu \mathrm{g} / \mathrm{ml} \mathrm{NAC:} 15.71 \pm 1.77 \%$, p $<0.01 ; 100 \mu \mathrm{g} / \mathrm{ml} \mathrm{LPS} \& 400 \mu \mathrm{g} / \mathrm{ml}$ NAC: $24.24 \pm 2.66, \mathrm{p}<0.001 ; 10 \mu \mathrm{g} / \mathrm{ml}$ LPS \& $800 \mu \mathrm{g} / \mathrm{ml} \mathrm{NAC:} 13.73 \pm 1.31 \%, \mathrm{p}<0.01 ; 100 \mu \mathrm{g} /$ $\mathrm{ml}$ LPS \& $800 \mu \mathrm{g} / \mathrm{ml}$ NAC: $17.50 \pm 1.47$, p<0.001) (Fig. 3B-I). To confirm the experimental results above, we further employed the in vitro explant culture assay of the chick embryo aortic arches as previously described [31], $1 \mu \mathrm{g} / \mathrm{ml}$ LPS in culture medium could stimulated the cell extension from the cultured explants of chick aortic arches. Again the LPS-stimulated cell extension from aortic arch explants was significantly regressed by addition of $1000 \mu \mathrm{g} /$ $\mathrm{ml} \mathrm{NAC}(1 \mu \mathrm{g} / \mathrm{ml}$ LPS: $421.4 \pm 3.293, \mathrm{p}<0.001 ; 1 \mu \mathrm{g} / \mathrm{ml}$ LPS \& $1000 \mu \mathrm{g} / \mathrm{ml}$ NAC: $359.2 \pm 25.98$, $\mathrm{p}<0.001$ ) (Fig. 3J-M), indicating that NAC administration indeed suppress LPS-induced angiogenesis.

NAC administration suppressed LPS-enhanced adhesion of endothelial cells and angiogenesis-related gene expressions on chick CAM

To investigate whether or not the integrity of blood vessels was altered in presence/ absence of LPS and/or NAC, we carried out the Evans blue perfusion experiments in chick

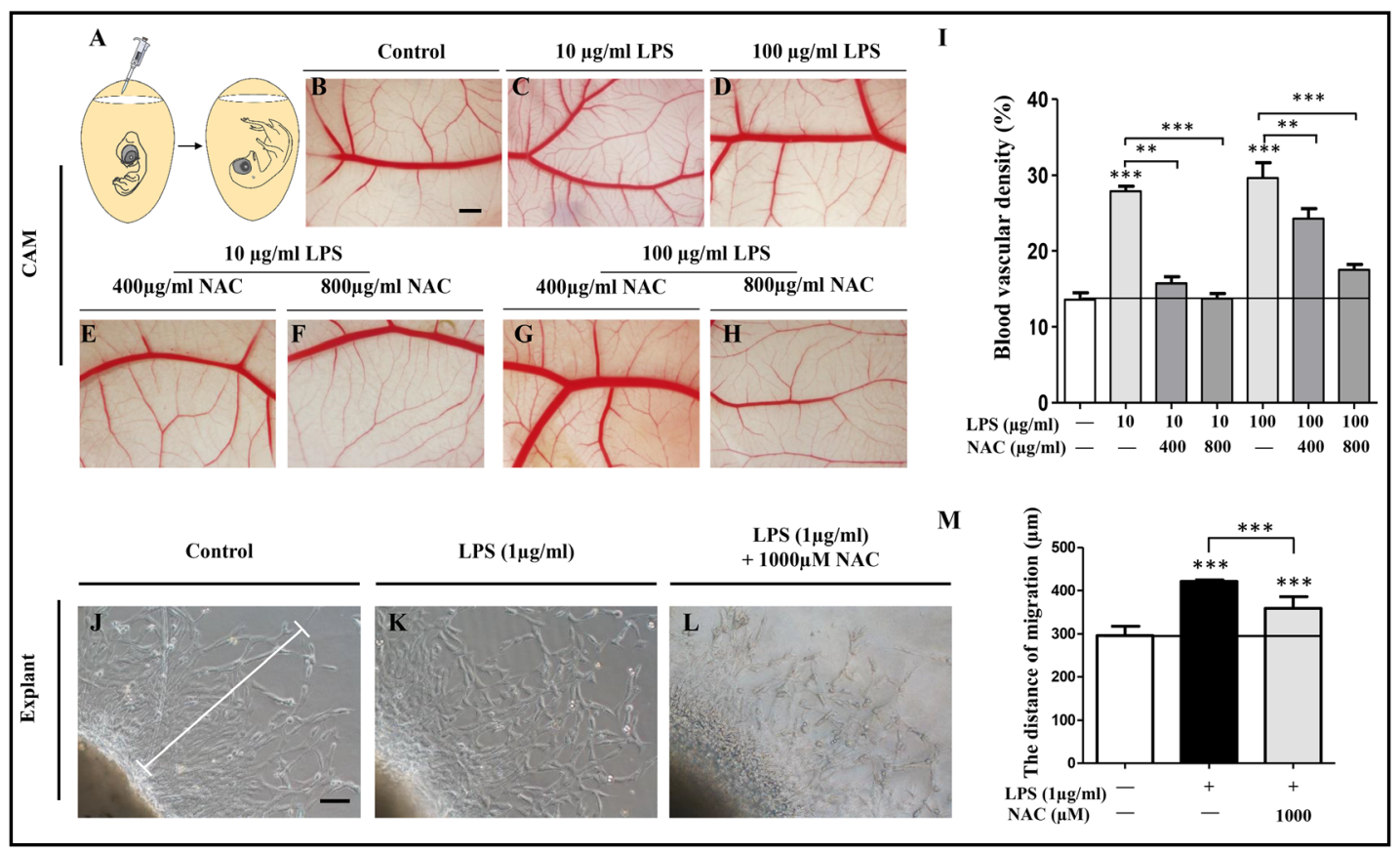

Fig. 3. Assessment of angiogenesis on chick CAM and in vitro explant culture in absence/presence of LPS and NAC. A: The sketches illustrate the same way to treat embryos as did in Fig. 2A. B-H: The representative bright-field image of angiogenesis on chick CAM exposed to simple saline (Control, B), 10 LPS (C), 100 LPS (D), 10 LPS + 400 NAC (E), 10 LPS + 800 NAC (F), 100 LPS + $400 \mathrm{NAC}(\mathrm{G})$, and $100 \mathrm{LPS}+800 \mathrm{NAC}(\mathrm{H})$ respectively. I: Bar chart showing the comparison of blood vascular densities on the CAM among control, 10 LPS, 100 LPS, 10 LPS + 400 NAC, 10 LPS + NAC, 100 LPS + 400 NAC, and 100 LPS + 800 NAC groups (n>3 CAM in each group). J-L: The representative bright-field images of the aortic arch explants from 13-day chick embryos were taken at in vitro 3-day incubation in presence of sample saline (Control, J), 1 LPS or 1 LPS + 1000 NAC groups. M: Bar chart showing the comparison of cell emigratory distances from the in vitrocultured aortic arch explants among control, 1 LPS and 1 LPS + 1000 NAC groups ( $n>3$ aortic arch explants in each group). Scale bars $=1 \mathrm{~mm}$ in B-H and $50 \mu \mathrm{m}$ in J-L.

\section{KARGER}


CAM model. The amount of Evans blue accumulated in the tissues is inversely related to the integrity of blood vessels. (Fig. 4B).

Furthermore, we determined gene expressions of tight junction and adherens junction molecules using quantitative PCR. Both 10 and $100 \mu \mathrm{g} / \mathrm{ml}$ LPS significantly increased gene expressions of tight junction molecules including Claudin-1, Claudin-5, Claudin-12, Z01, ZO2 in chick CAM. Increased expression of these genes was blunted by NAC in a dose-dependent manner (except for Claudin-12 and ZO-2 in the $10 \mu \mathrm{g} / \mathrm{ml} \mathrm{LPS}+400 \mu \mathrm{g} / \mathrm{ml} \mathrm{NAC} \mathrm{groups)} \mathrm{(Fig.}$ $4 \mathrm{C}-\mathrm{G}$ ). Both dosages of LPS administration also significantly increased the expressions of VEcadherin, $\beta$-catenin, Plakoglobin, Vinculin and Par3; the addition of 400 or $800 \mu \mathrm{g} / \mathrm{ml} \mathrm{NAC}$ suppressed the LPS-enhanced expressions of Plakoglobin and Vinculin (Fig. 4H-L). 10 and $100 \mu \mathrm{g} / \mathrm{ml}$ LPS significantly increased gene expressions of Ang2, VEGFR3 and FGF2 on chick CAM. Addition of 400 or $800 \mu \mathrm{g} / \mathrm{ml}$ NAC suppressed LPS-enhanced expressions of these genes (Fig. 5F, H, I). On the contrary, both 10 and $100 \mu \mathrm{g} / \mathrm{ml}$ LPS inhibited the expressions of Ang1 and VEGFR2 on chick CAM, and the expressions of Ang1 and VEGFR2 gradually rose by the addition of 400 or $800 \mu \mathrm{g} / \mathrm{ml} \mathrm{NAC} \mathrm{(Fig.} \mathrm{5G,} \mathrm{J).}$

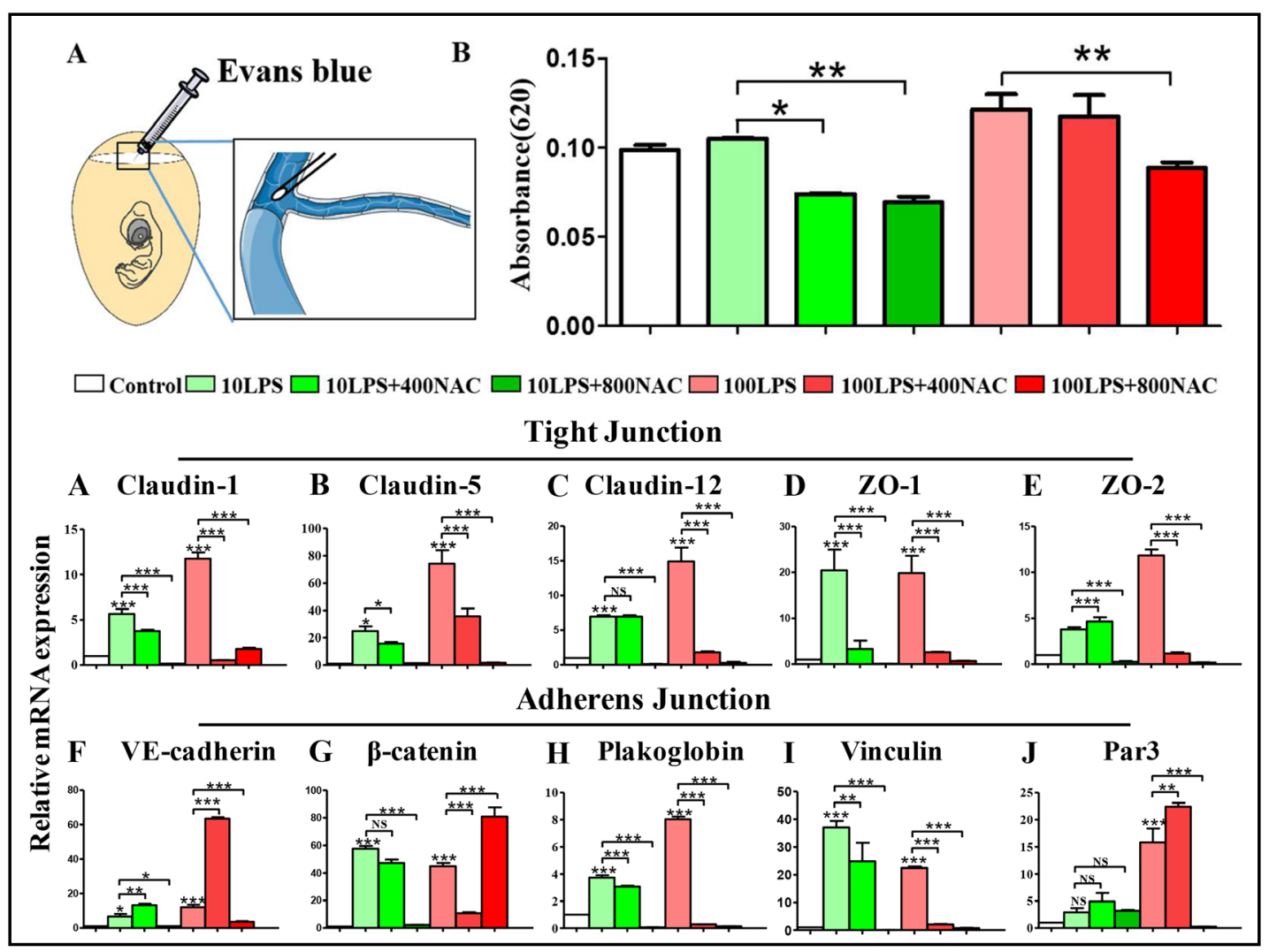

Fig. 4. Assessment of vascular integrity and gene expression of genes involved in tight-junction adhesion molecules, modulation of subcellular distribution of junctions, cell polarity proteins, junction formation and epithelial polarization in chick CAM in absence/presence of LPS and NAC. A: Sketches illustrates how Evans blue was injected into the blood vessel. B: Bar graphs showing blood vessel integrity. The amount of Evans blue accumulated in the tissues is inversely related to the integrity of blood vessels. C-L: Quantitative PCR data showing gene expressions of Claudin-1 (C), Claudin-5 (D), Claudin-12 (E), ZO-1 (F), ZO-2 (G), VECadherin (H), $\beta$-catenin (I), Plakoglobin (J), Vinculin (K) and Par3 (L) in control, $10 \mu \mathrm{g} / \mathrm{ml} \mathrm{LPS,} 10 \mu \mathrm{g} / \mathrm{ml} \mathrm{LPS}$ $+400 \mu \mathrm{g} / \mathrm{ml} \mathrm{NAC}, 10 \mu \mathrm{g} / \mathrm{ml} \mathrm{LPS}+800 \mu \mathrm{g} / \mathrm{ml} \mathrm{NAC}, 100 \mu \mathrm{g} / \mathrm{ml} \mathrm{LPS}, 100 \mu \mathrm{g} / \mathrm{ml} \mathrm{LPS}+400 \mu \mathrm{g} / \mathrm{ml} \mathrm{NAC}$, and 100 $\mu \mathrm{g} / \mathrm{ml} \mathrm{LPS}+800 \mu \mathrm{g} / \mathrm{ml}$ NAC groups. Each of these experiments was replicated at least three times. $\left({ }^{*} \mathrm{P}<0.05\right.$, ${ }^{* *} \mathrm{P}<0.01,{ }^{* * *} \mathrm{P}<0.001$ versus controls). 


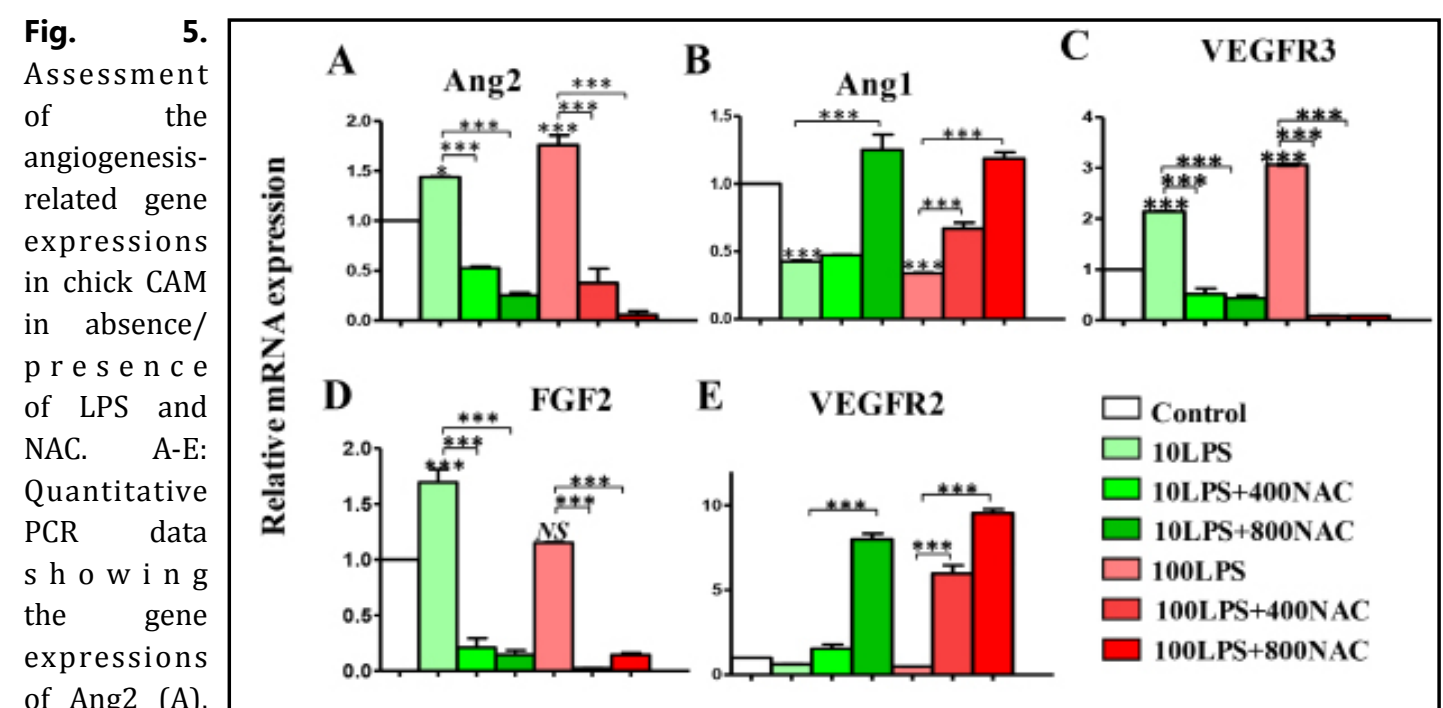

\section{Ang1 (B),}

VEGFR3 (C), FGF2 (D), and VEGFR2 (E)in control, $10 \mu \mathrm{g} / \mathrm{ml} \mathrm{LPS,} 10 \mu \mathrm{g} / \mathrm{ml} \mathrm{LPS}+400 \mu \mathrm{g} / \mathrm{ml} \mathrm{NAC,} 10 \mu \mathrm{g} / \mathrm{ml}$ LPS $+800 \mu \mathrm{g} / \mathrm{ml} \mathrm{NAC}, 100 \mu \mathrm{g} / \mathrm{ml} \mathrm{LPS}, 100 \mu \mathrm{g} / \mathrm{ml} \mathrm{LPS}+400 \mu \mathrm{g} / \mathrm{ml} \mathrm{NAC}$, and $100 \mu \mathrm{g} / \mathrm{ml} \mathrm{LPS}+800 \mu \mathrm{g} / \mathrm{ml}$ NAC groups. Each of these experiments was replicated at least three times. $\left({ }^{*} \mathrm{P}<0.05,{ }^{* *} \mathrm{P}<0.01,{ }^{* * *} \mathrm{P}<0.001\right.$ versus controls).

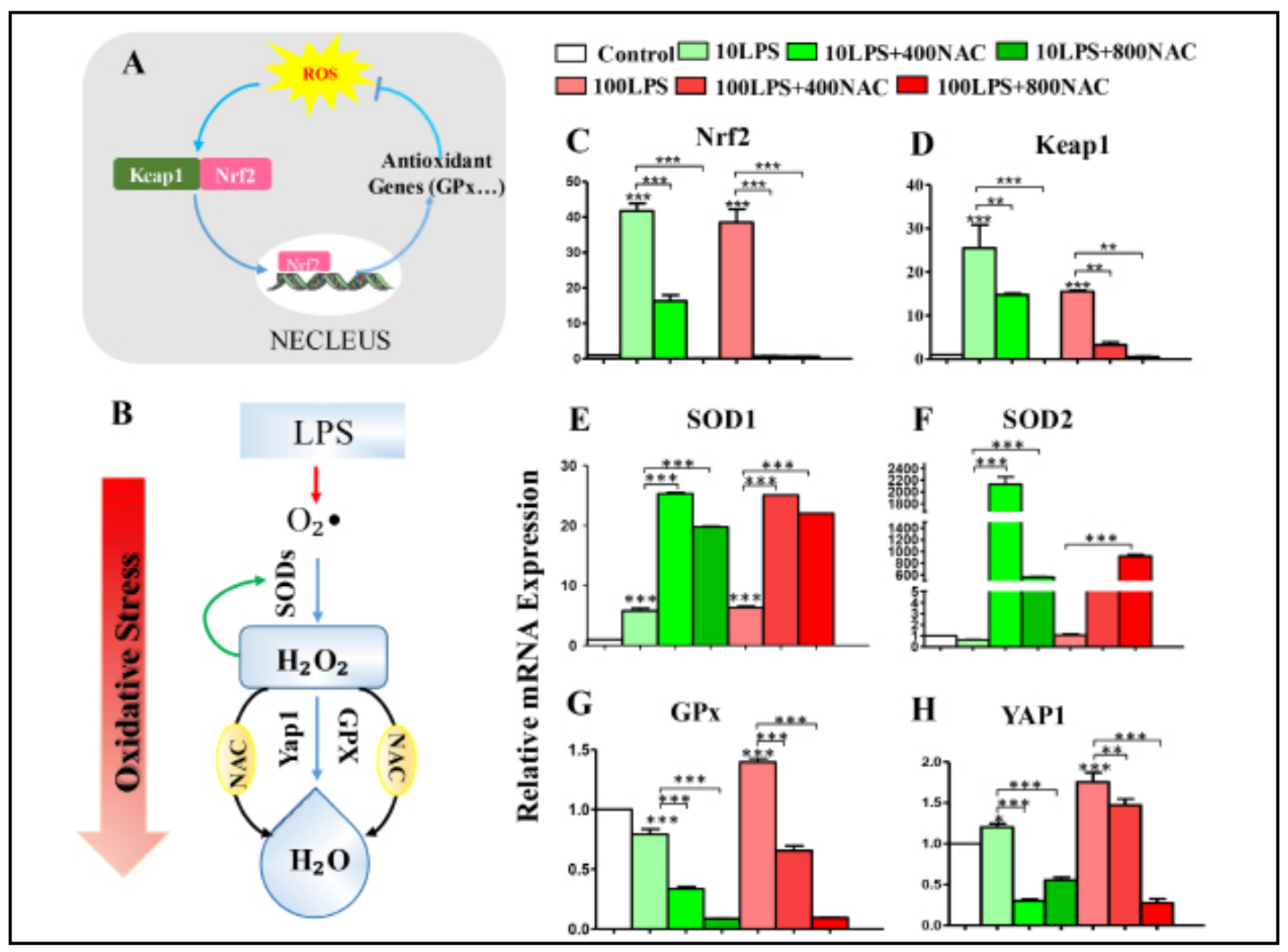

Fig. 6. Assessment of the oxidative stress-related gene expressions in chick CAM in absence/presence of LPS and NAC. A: Sketches illustrating key genes involved in oxidative stress regulation. B :Potential effects of LPS on genes involved in oxidative stress. C-H: Gene expressions of Nrf2 (C), Keap1 (D), SOD1 (E), SOD2 (F), GPx (G), and YAP1 (H) in control, $10 \mu \mathrm{g} / \mathrm{ml} \mathrm{LPS,} 10 \mu \mathrm{g} / \mathrm{ml} \mathrm{LPS}+400 \mu \mathrm{g} / \mathrm{ml} \mathrm{NAC}, 10 \mu \mathrm{g} / \mathrm{ml} \mathrm{LPS}+800 \mu \mathrm{g} / \mathrm{ml}$ $\mathrm{NAC}, 100 \mu \mathrm{g} / \mathrm{ml} \mathrm{LPS}, 100 \mu \mathrm{g} / \mathrm{ml} \mathrm{LPS}+400 \mu \mathrm{g} / \mathrm{ml} \mathrm{NAC}$, and $100 \mu \mathrm{g} / \mathrm{ml} \mathrm{LPS}+800 \mu \mathrm{g} / \mathrm{ml} \mathrm{NAC}$. Each of these experiments was replicated at least three times. $\left({ }^{*} \mathrm{P}<0.05,{ }^{* *} \mathrm{P}<0.01,{ }^{* * *} \mathrm{P}<0.001\right.$ versus controls). 


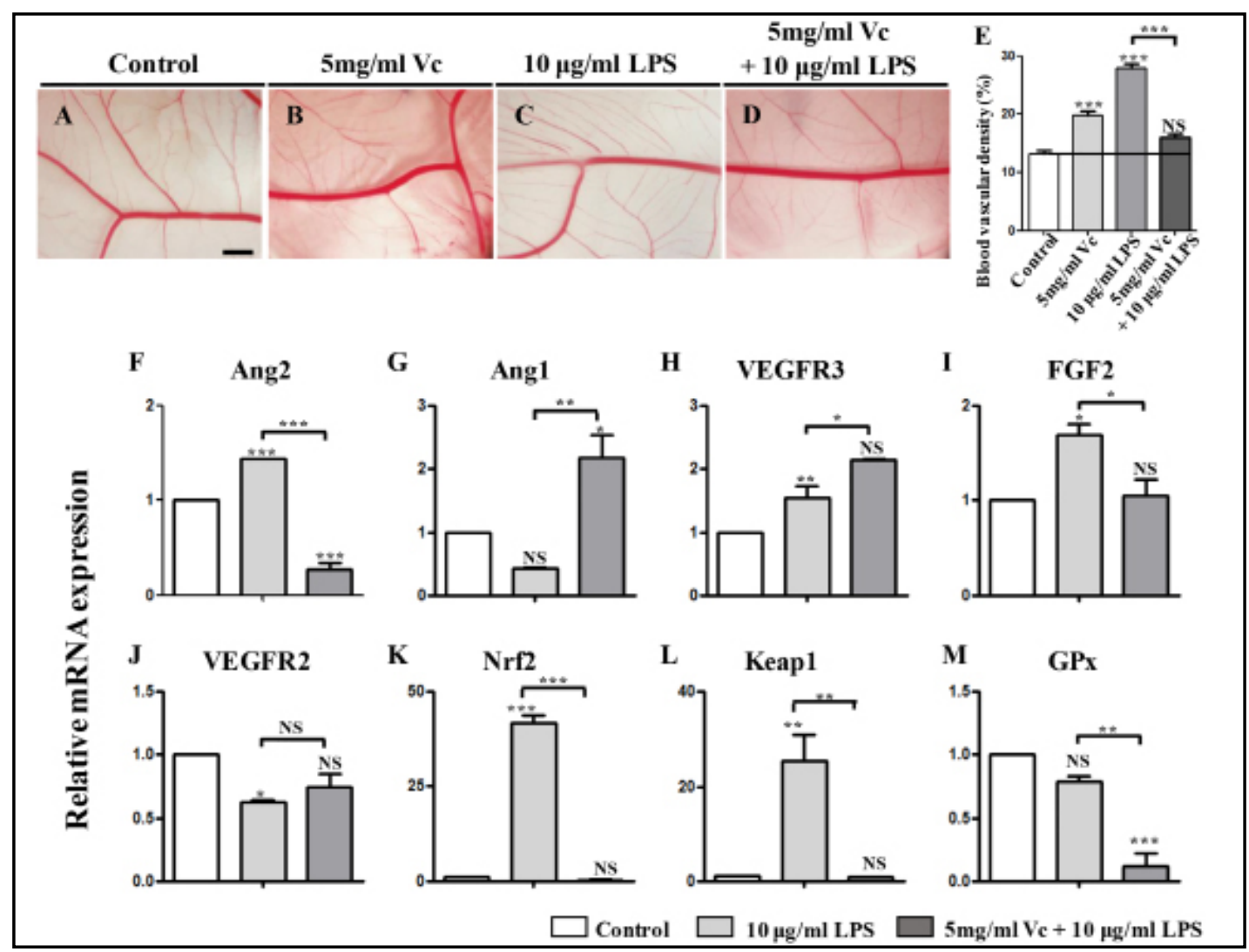

Fig. 7. Assessment of Vitamin C (Vc) effects on angiogenesis in presence/absence of LPS. A-D: Representative bright-field images of angiogenesis on chick CAM exposed to saline (Control, A), $5 \mathrm{mg} / \mathrm{ml} \mathrm{Vc} \mathrm{(B),} 10 \mu \mathrm{g} /$ $\mathrm{ml}$ LPS (B), $10 \mu \mathrm{g} / \mathrm{ml}$ LPS $+5 \mathrm{mg} / \mathrm{ml}$ Vc (D) , respectively. E: Bar chart showing the comparison of blood vascular densities on the CAM in control, $5 \mathrm{mg} / \mathrm{ml} \mathrm{Vc}, 10 \mu \mathrm{g} / \mathrm{ml} \mathrm{LPS}, 10 \mu \mathrm{g} / \mathrm{ml} \mathrm{LPS}+5 \mathrm{mg} / \mathrm{ml} \mathrm{Vc}(\mathrm{n}>3 \mathrm{CAMs}$ in each group). F-M: Quantitative PCR data show the gene expressions of Ang2 (F), Ang1 (G), VEGFR3 (H), FGF2 (I), and VEGFR2 (J), Nrf2 (K), Keap1 (L), GPx (M) in control embryos, embryos treated with 5 mg/ $\mathrm{ml} \mathrm{Vc}, 10 \mu \mathrm{g} / \mathrm{ml} \mathrm{LPS}, 10 \mu \mathrm{g} / \mathrm{ml} \mathrm{LPS}+5 \mathrm{mg} / \mathrm{ml} \mathrm{Vc}$, respectively (Each of these experiments was replicated at least three times). ${ }^{*} \mathrm{P}<0.05,{ }^{* *} \mathrm{P}<0.01,{ }^{* * *} \mathrm{P}<0.001$. Scale bars $=1 \mathrm{~mm}$ in A-C.

\section{Oxidative stress is closely related to NAC-suppressed angiogenesis induced by LPS on chick CAM}

It is well known that external environment factors often interferes with embryonic angiogenesis through excessive ROS production [34].Using quantitative PCR, we determined the expressions of oxidative stress-related genes (Fig. 6A-B) on chick CAM in absence/ presence of LPS or/and NAC. The results showed that both of 10 and $100 \mu \mathrm{g} / \mathrm{ml} \mathrm{LPS}$ significantly increased the expressions of Nrf2, Keap1, SOD1, SOD2, GPx and YAP1 genes in chick CAM (Figs. 6C-H); addition of 400 or $800 \mu \mathrm{g} / \mathrm{ml} \mathrm{NAC}$ suppressed the LPS-enhanced expressions of GPx, YAP1, Nrf2, , and Keap1genes (Fig. 6E, F, G, H). Addition of 400 or $800 \mu \mathrm{g} /$ $\mathrm{ml} \mathrm{NAC}$ to the test system even raised the expressions of SOD1 and SOD2 genes.

Besides, we also investigated the effects of another antioxidant - Vitamin C (Vc) - on angiogenesis in this model, and the result showed that Vitamin $\mathrm{C}(5 \mathrm{mg} / \mathrm{ml})$ significantly affected the angiogenesis on CAM (Fig. 7B) as well as the blood vascular densities of the vascular nets on chick CAM ( $5 \mathrm{mg} / \mathrm{ml} \mathrm{Vc:} 19.81 \pm 0.63, \mathrm{p}<0.001$; Fig. $7 \mathrm{E})$. The LPS-induced angiogenesis was significantly suppressedby addition of $5 \mathrm{mg} / \mathrm{ml}$ Vc. $(10 \mu \mathrm{g} / \mathrm{ml} \mathrm{LPS}$ : 27.86 $\pm 1.35, \mathrm{p}<0.001 ; 10 \mu \mathrm{g} / \mathrm{ml}$ LPS $+5 \mathrm{mg} / \mathrm{ml} \mathrm{Vc:} 16.63 \pm 0.64, \mathrm{p}<0.001$ ) (Fig. 7E).

The expressions of key genes on chick CAM were assessed using quantitative PCR following the exposure of $5 \mathrm{mg} / \mathrm{ml} \mathrm{Vc}$ (Fig. 7F-J). $10 \mu \mathrm{g} / \mathrm{ml}$ LPS significantly increased

\section{KARGER}




\section{Cellular Physiology Cell Physiol Biochem 2018;49:2483-2495 \\ and Biochemistry Published onIne:28 September $2018 \begin{aligned} & \text { DOI: } 2018 \text { The Author(s). Published by S. Karger AG, Basel } \\ & \text { www.karger.com/cpb }\end{aligned}$ \\ Zhang et al.: NAC Suppresses LPS-Induced Pathological Angiogenesis}

the gene expressions of Ang2, VEGFR3 and FGF2 on chick CAM. Addition of $5 \mathrm{mg} / \mathrm{ml} \mathrm{Vc}$ suppressed the LPS-enhanced the expressions of these genes (Fig. 7F, H, I). $10 \mu \mathrm{g} / \mathrm{ml} \mathrm{LPS}$ inhibited the expressions of Ang1 and VEGFR2 on chick CAM, and the expressions of Ang1 and VEGFR2 gradually rose by the addition of $5 \mathrm{mg} / \mathrm{ml} \mathrm{Vc} \mathrm{(Fig.} \mathrm{7G,} \mathrm{J).}$

We also determined the expressions of oxidative stress-related genes (Fig. 7K-M) on chick CAM in absence/presence of LPS or/and Vitamin C. The results showed that $10 \mu \mathrm{g} /$ ml LPS significantly increased the expressions of Nrf2, Keap1 and GPx genes on chick CAM.

\section{Discussion}

The chick embryo model has been extensively used to investigate the birth defects in various organ systems [35-40]. In the current study, we used chick embryos and chick chorioallantoic membrane (CAM) as an in vivo angiogenesis model to analyze the effects of N-acetylcysteine (NAC) on LPS-induced pathological angiogenesis. The chick gastrula embryos and CAM are an excellent model for studying angiogenesis because they are easily accessible for experimental manipulations and angiogenesis could be observed and analyzed easily as previously described $[41,42]$. The chick CAM normally provides the developing embryo with nutrients. The highly vascularization of CAM makes it an excellent model for studying the formation of blood vessels in presence of any compound of interest. Moreover, the results produced are highly reproducible, because NAC concentrations as well as other factors influencing embryonic growth can be strictly controlled in EC culture medium (see Fig. 1).

Our study demonstrated that NAC on its own did not affect angiogenesis in the chick embryo model, but regulates genes expression of enzymes involved in oxidative stress (Fig. 2). Angiogenesis could be induced by administration of lipopolysaccharide (LPS) in CAM. We suggest that this effect is mediated via the LDS receptor being detectable on chicken CAM (unpublished data). LPS substantially induces angiogenesis in chicken CAM, this process, however, could be abolished by NAC treatment (Fig. 3). Using chicken embryo aortic arch assay, we also obtainedsimilar results showing that NAC administration normalized the LPSenhanced cell extension from the cultured explants of chick embryo aortic arches (Fig. 3). These data are in agreement with previous reports showing that LPS induces endothelial sprouting and angiogenesis via stimulating the release of growth factors or cytokines [43].

The LPS-stimulated angiogenesis was accompanied by an upregulation of genes (Fig. 4) involved in tight-junction adhesion molecules, but also modulation of subcellular distribution of junction and cell polarity proteins, resulting in junction formation and epithelial polarization [44]. These gene expressions were raised following the LPS exposure and most of them dropped by the addition of NAC (Fig. 4), which shows the same patternas seen on blood vessel density in presence of LPS/NAC, suggesting an antagonism of NAC on inflammation-induced pathological angiogenesis. FGF-2 and VEGF are key inducers of angiogenesis [45] and HIF2 (hypoxia-inducible transcription factor 2) plays an important role in blood vessel remodeling [46]. The followed experiments about the LPS/NAC-altered expressions of VEGFR2-3 and FGF2, as well as Ang1 and Ang2, the key genes on maintaining vascular endothelium integrity [47], likewise support the restoring effect of NAC on aberrant angiogenesis (Fig. 5).

To elucidate the underlying mechanism of NAC's restoring effect on LPS-induced pathological angiogenesis, we focused onthe antioxidative potential of NAC. We observed that LPS-enhanced the expressions of Nrf2 and Keap1, the key antioxidative genes. NAC normalized expression of these genes. Moreover, the expressions of key redox enzyme genes such as SOD, GPx and YAP1 showed likewise a trend towards normal expression after NAC treatment (Fig. 6). We found that Vitamin C (a well-known antioxidant drug) could effectively inhibited LPS-induced angiogenesis as well (Fig. 7). These findings suggest that the NAC as antioxidant is able to restore pathological angiogenesis at least partially by modulation genes involved in oxidative stress. 


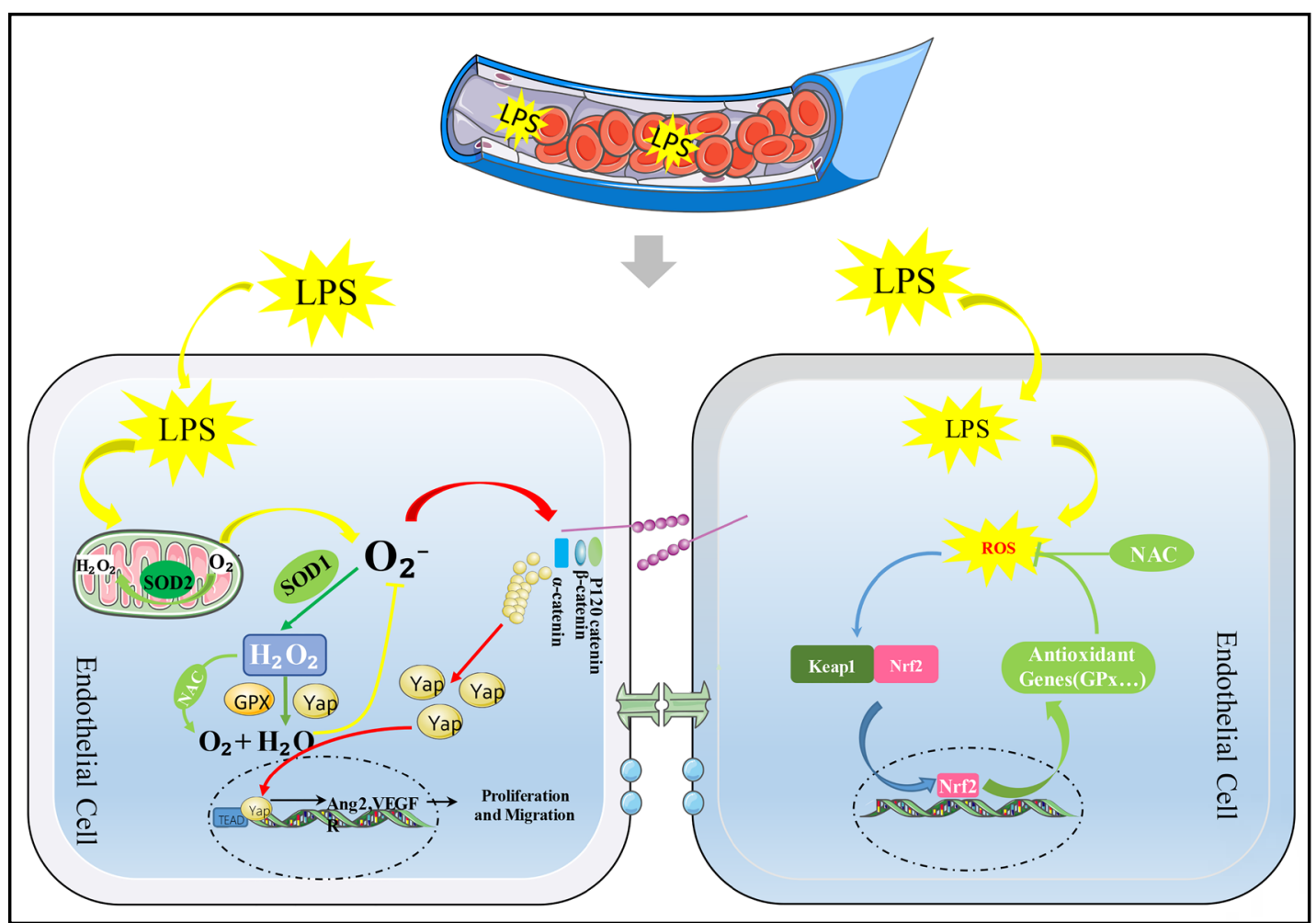

Fig. 8. Hypothetic model illustrating how NAC blunts LPS induced angiogenesis.

It is a clear study limitation that we only analyzed NAC as antioxidant. Thus is is unclear so far weather or not the observed NAC effects are compound specific or a class effect of antioxidants in general.

\section{Conclusion}

In summary (Fig. 8), we established a LPS-induced angiogenesis model in chick CAM. NAC administration could effectively inhibit LPS-induced angiogenesis and restore the integrity of endothelium on chick CAM. LPS exposure caused an increased expression of genes involved in oxidative stress in chick CAM, and NAC administration could abolish this effect. We recently demonstrated in the same model that combined ETA/ETB receptor blocade is likewise an effective pharmaceutical approach to inhibit LPS-induced angiogenesis [48]. It would be of interest to see wheater an combination of both strategies potentiate the inhibition on LPS-induced angiogenesis.

Our current studies suggest that NAC might act as a potential drug for the treatment of pathological angiogenesis in clinical practice as well, however, more experiments in models closer to clinical situation are clearly needed.

\section{Acknowledgements}

This study was supported by NSFC grant $(31771331,81741016)$, Science and Technology Planning Project of Guangdong Province (2017A020214015, 2017A050506029, 2016B030229002), Science and Technology Program of Guangzhou (201710010054), Guangdong Natural Science Foundation (2016A030311044), Special fund for science and technology innovation of Guangdong College Student (pdjh2016a0054) and Students Research Training Program Fund (cx15195, cx16018, 201710559037). 


\section{Cellular Physiology Cell Physiol Biochem 2018;49:2483-2495

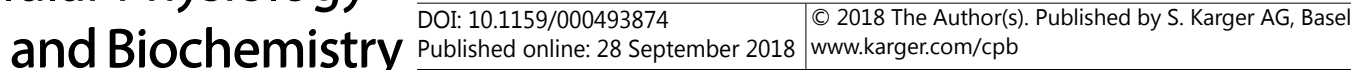 \\ Zhang et al.: NAC Suppresses LPS-Induced Pathological Angiogenesis}

\section{Disclosure Statement}

The authors declare that there are no competing financial interests.

\section{References}

1 Lu YP, Reichetzeder C, Prehn C, Yin LH, Yun C, Zeng S, Chu C, Adamski J, Hocher B: Cord blood lysophosphatidylcholine 16: 1 is positively associated with birth weight. Cell Physiol Biochem 2018;45:614-624.

2 Reichetzeder C, Dwi Putra SE, Li J, Hocher B: Developmental origins of disease - crisis precipitates change. Cell Physiol Biochem 2016;39:919-938.

3 Chung AS, Ferrara N: Developmental and pathological angiogenesis. Annu Rev Cell Dev Biol 2011;27:563584.

4 Patan S: Vasculogenesis and angiogenesis. Cancer Treat Res 2004;117:3-32.

5 Holmes DI, Zachary I: The vascular endothelial growth factor (vegf) family: Angiogenic factors in health and disease. Genome Biol 2005;6:209.

6 Thurston G: Role of angiopoietins and tie receptor tyrosine kinases in angiogenesis and lymphangiogenesis. Cell Tissue Res 2003;314:61-68.

7 Cao R, Brakenhielm E, Pawliuk R, Wariaro D, Post MJ, Wahlberg E, Leboulch P, Cao Y: Angiogenic synergism, vascular stability and improvement of hind-limb ischemia by a combination of pdgf-bb and fgf-2. Nat Med 2003;9:604-613.

$>8$ Chan EC, Liu GS, Dusting GJ: Redox mechanisms in pathological angiogenesis in the retina: Roles for nadph oxidase. Curr Pharm Des 2015;21:5988-5998.

$>9$ Lee SL, Rouhi P, Dahl Jensen L, Zhang D, Ji H, Hauptmann G, Ingham P, Cao Y: Hypoxia-induced pathological angiogenesis mediates tumor cell dissemination, invasion, and metastasis in a zebrafish tumor model. Proc Natl Acad Sci U S A 2009;106:19485-19490.

10 Dace DS, Khan AA, Kelly J, Apte RS: Interleukin-10 promotes pathological angiogenesis by regulating macrophage response to hypoxia during development. PLoS One 2008;3:e3381.

11 Zhang Y, Han Q, Ru Y, Bo Q Wei RH: Anti-vegf treatment for myopic choroid neovascularization: From molecular characterization to update on clinical application. Drug Des Devel Ther 2015;9:3413-3421.

12 Pollet I, Opina CJ, Zimmerman C, Leong KG, Wong F, Karsan A: Bacterial lipopolysaccharide directly induces angiogenesis through traf6-mediated activation of nf-kappab and c-jun n-terminal kinase. Blood 2003;102:1740-1742.

-13 Mattsby-Baltzer I, Jakobsson A, Sorbo J, Norrby K: Endotoxin is angiogenic. Int J Exp Pathol 1994;75:191196.

14 Simon F, Fernandez R: Early lipopolysaccharide-induced reactive oxygen species production evokes necrotic cell death in human umbilical vein endothelial cells. J Hypertens 2009;27:1202-1216.

15 Wang T, Qin L, Liu B, Liu Y, Wilson B, Eling TE, Langenbach R, Taniura S, Hong JS: Role of reactive oxygen species in lps-induced production of prostaglandin e2 in microglia. J Neurochem 2004;88:939-947.

-16 Bist G, Pun NT, Magar TB, Shrestha A, Oh HJ, Khakurel A, Park PH, Lee ES: Inhibition of lps-stimulated ros production by fluorinated and hydroxylated chalcones in raw 264.7 macrophages with structure-activity relationship study. Bioorg Med Chem Lett 2017;27:1205-1209.

17 Giordano FJ: Oxygen, oxidative stress, hypoxia, and heart failure. J Clin Invest 2005;115:500-508.

18 Sawyer DB, Siwik DA, Xiao L, Pimentel DR, Singh K, Colucci WS: Role of oxidative stress in myocardial hypertrophy and failure. J Mol Cell Cardiol 2002;34:379-388.

19 Murdoch CE, Zhang M, Cave AC, Shah AM: Nadph oxidase-dependent redox signalling in cardiac hypertrophy, remodelling and failure. Cardiovasc Res 2006;71:208-215.

20 Valko M, Leibfritz D, Moncol J, Cronin MT, Mazur M, Telser J: Free radicals and antioxidants in normal physiological functions and human disease. Int J Biochem Cell Biol 2007;39:44-84.

21 Karbownik M, Lewinski A: The role of oxidative stress in physiological and pathological processes in the thyroid gland; possible involvement in pineal-thyroid interactions. Neuro Endocrinol Lett 2003;24:293303.

22 Singal PK, Bello-Klein A, Farahmand F, Sandhawalia V: Oxidative stress and functional deficit in diabetic cardiomyopathy. Adv Exp Med Biol 2001;498:213-220.

-23 Bavarsad Shahripour R, Harrigan MR, Alexandrov AV: N-acetylcysteine (nac) in neurological disorders: Mechanisms of action and therapeutic opportunities. Brain Behav 2014;4:108-122.

24 Elbini Dhouib I, Jallouli M, Annabi A, Gharbi N, Elfazaa S, Lasram MM: A minireview on n-acetylcysteine: An old drug with new approaches. Life Sci 2016;151:359-363. 


\section{Cellular Physiology Cell Physiol Biochem 2018;49:2483-2495 \begin{tabular}{l|l|l} 
and Biochemistry & DOI: 10.1159/000493874 & $\begin{array}{l}\text { C) } 2018 \text { The Author(s). Published by S. Karger AG, Basel } \\
\text { www.karger.com/cpb }\end{array}$ \\
\hline
\end{tabular}}

25 Dekhuijzen PN: Antioxidant properties of n-acetylcysteine: Their relevance in relation to chronic obstructive pulmonary disease. Eur Respir J 2004;23:629-636.

-26 Decramer M, Rutten-van Molken M, Dekhuijzen PN, Troosters T, van Herwaarden C, Pellegrino R, van Schayck CP, Olivieri D, Del Donno M, De Backer W, Lankhorst I, Ardia A: Effects of n-acetylcysteine on outcomes in chronic obstructive pulmonary disease (bronchitis randomized on nac cost-utility study, broncus): A randomised placebo-controlled trial. Lancet 2005;365:1552-1560.

-27 Hamburger V, Hamilton HL: A series of normal stages in the development of the chick embryo. 1951. Dev Dyn 1992;195:231-272.

28 Chapman SC, Collignon J, Schoenwolf GC, Lumsden A: Improved method for chick whole-embryo culture using a filter paper carrier. Dev Dyn 2001;220:284-289.

29 Cheng X, Luo R, Wang G, Xu CJ, Feng X, Yang RH, Ding E, He YQ Chuai M, Lee KK, Yang X: Effects of 2, 5-hexanedione on angiogenesis and vasculogenesis in chick embryos. Reprod Toxicol 2015;51:79-89.

-30 He YQ, Li Y, Wang XY, He XD, Jun L, Chuai M, Lee KK, Wang J, Wang LJ, Yang X: Dimethyl phenyl piperazine iodide (dmpp) induces glioma regression by inhibiting angiogenesis. Exp Cell Res 2014;320:354-364.

31 Nicosia RF, Ottinetti A: Growth of microvessels in serum-free matrix culture of rat aorta. A quantitative assay of angiogenesis in vitro. Lab Invest 1990;63:115-122.

-32 Hamer PW, McGeachie JM, Davies MJ, Grounds MD: Evans blue dye as an in vivo marker of myofibre damage: Optimising parameters for detecting initial myofibre membrane permeability. J Anat 2002;200:6979.

-33 Patterson CE, Rhoades RA, Garcia JG: Evans blue dye as a marker of albumin clearance in cultured endothelial monolayer and isolated lung. J Appl Physiol (1985) 1992;72:865-873.

34 Wang G, Zhong S, Zhang SY, Ma ZL, Chen JL, Lu WH, Cheng X, Chuai M, Lee KK, Lu DX, Yang X: Angiogenesis is repressed by ethanol exposure during chick embryonic development. J Appl Toxicol 2016;36:692-701.

-35 Bupp Becker SR, Shibley IA, Jr.: Teratogenicity of ethanol in different chicken strains. Alcohol Alcohol 1998;33:457-464.

36 Illanes J, Fuenzalida M, Romero S, Gonzalez P, Lemus D: Ethanol effect on the chick embryo ossification: A macroscopic and microscopic study. Biol Res 1999;32:77-84.

-37 Cavieres MF, Smith SM: Genetic and developmental modulation of cardiac deficits in prenatal alcohol exposure. Alcohol Clin Exp Res 2000;24:102-109.

38 Debelak KA, Smith SM: Avian genetic background modulates the neural crest apoptosis induced by ethanol exposure. Alcohol Clin Exp Res 2000;24:307-314.

-39 Roda-Moreno JA, Pascual-Morenilla MT, Roda-Murillo O, Lopez-Soler M, Arrebola-Nacle F: Action of ethanol on different skull and brain parameters in the chick embryo. J Craniofac Genet Dev Biol 2000;20:44-48.

40 Miller RR, Jr., Heckel CD, Koss WJ, Montague SL, Greenman AL: Ethanol- and nicotine-induced membrane changes in embryonic and neonatal chick brains. Comp Biochem Physiol C Toxicol Pharmacol 2001;130:163-178.

41 He RR, Li Y, Li XD, Yi RN, Wang XY, Tsoi B, Lee KK, Abe K, Yang X, Kurihara H: A new oxidative stress model, 2, 2-azobis(2-amidinopropane) dihydrochloride induces cardiovascular damages in chicken embryo. PLoS One;8:e57732.

$>42$ He YQ, Li Y, Wang XY, He XD, Jun L, Chuai M, Lee KK, Wang J, Wang LJ, Yang X: Dimethyl phenyl piperazine iodide (dmpp) induces glioma regression by inhibiting angiogenesis. Exp Cell Res;320:354-364.

43 Yoshida S, Ono M, Shono T, Izumi H, Ishibashi T, Suzuki H, Kuwano M: Involvement of interleukin-8, vascular endothelial growth factor, and basic fibroblast growth factor in tumor necrosis factor alphadependent angiogenesis. Mol Cell Biol 1997;17:4015-4023.

44 Satohisa S, Chiba H, Osanai M, Ohno S, Kojima T, Saito T, Sawada N: Behavior of tight-junction, adherensjunction and cell polarity proteins during hnf-4alpha-induced epithelial polarization. Exp Cell Res 2005;310:66-78.

45 Seghezzi G, Patel S, Ren CJ, Gualandris A, Pintucci G, Robbins ES, Shapiro RL, Galloway AC, Rifkin DB, Mignatti P: Fibroblast growth factor-2 (fgf-2) induces vascular endothelial growth factor (vegf) expression in the endothelial cells of forming capillaries: An autocrine mechanism contributing to angiogenesis. J Cell Biol 1998;141:1659-1673.

46 Favier J, Lapointe S, Maliba R, Sirois MG: Hif2 alpha reduces growth rate but promotes angiogenesis in a mouse model of neuroblastoma. BMC Cancer 2007;7:139.

47 Lobov IB, Brooks PC, Lang RA: Angiopoietin-2 displays vegf-dependent modulation of capillary structure and endothelial cell survival in vivo. Proc Natl Acad Sci U S A 2002;99:11205-11210.

48 Wang G, Li PZ, Zhang SY, Zhong S, Chu C, Zeng S, Yan Y, Cheng X, Chuai B, Hocher B, Yang X: Lipopolysaccharides (LPS) Induced Angiogenesis During Chicken Embryogenesis is Abolished by Combined ETA/ETB Receptor Blockade. Cell Physiol Biochem 2018;48:2084-2090. 